\title{
Resilience of Sphyrna lewini, Rhizoprionodon longurio, and Carcharhinus falciformis at the entrance to the Gulf of California after three decades of exploitation
}

\section{Resiliencia de Sphyrna lewini, Rhizoprionodon longurio y Carcharhinus falciformis en la entrada del golfo de California después de tres décadas de explotación}

\author{
Emmanuel Furlong-Estrada ${ }^{*}$, Javier Tovar-Ávila², Juan Carlos Pérez-Jiménez ${ }^{3}$, Eduardo Ríos-Jara ${ }^{1}$ \\ ${ }^{1}$ Departamento de Ecología, Centro Universitario de Ciencias Biológicas y Agropecuarias, Km 15.5 carretera \\ Guadalajara-Nogales, CP 45110 Zapopan, Jalisco, México. \\ 2 Centro Regional de Investigación Pesquera-Bahía de Banderas, Instituto Nacional de Pesca, Calle Tortuga \#1, \\ La Cruz de Huanacaxtle, CP 63732 Nayarit, México. \\ ${ }^{3}$ El Colegio de la Frontera Sur, Av. Rancho Polígono 2-A, Ciudad Industrial, CP 24500 Lerma, Campeche, \\ México. \\ * Corresponding author. E-mail: efurlong49@hotmail.com
}

\begin{abstract}
Given their biological characteristics, sharks exhibit low resilience and thereby are considered a fishery resource particularly vulnerable to overfishing. Yet, for several decades, three shark species (Sphyrna lewini, Rhizoprionodon longurio, and Carcharhinus falciformis) have contributed consistently to the catches of the artisanal shark fishery at the entrance to the Gulf of California, showing a certain degree of resilience. The aim of this study was to estimate their capacity to recover from disturbances, based on their rebound potential $\left(r_{2 \mathrm{M}}\right)$, and analyze the factors that may be favoring their capacity to recover from fishing pressure in the region. Catch records, size composition of landings reported in previous studies and from undertaken surveys, as well as published information on life history parameters were used in the present analysis. Rhizoprionodon longurio showed high productivity $\left(r_{2 \mathrm{M}}=0.083\right)$ and thus high resilience, whereas $C$. falciformis and S. lewini presented medium productivities $\left(r_{2 \mathrm{M}}=0.053\right.$ and 0.062 , respectively), but alternative scenarios to consider uncertainty in the life history parameters of $C$. falciformis and S. lewini placed them in the low productivity category. All species presented low productivity when the more conservative natural mortality (e.g., $1.25 M$ ) to achieve maximum sustainable yield was considered. Catches were dominated by juveniles of $S$. lewini, and by preadults and adults of $R$. longurio and C. falciformis during all the analyzed period; this and their consistent contribution to landings suggest apparent population stability. Such stability might be related to their biological productivity, elasticity, wide distribution range, migratory habits, and size segregation. Nonetheless, changes that occurred in this fishery over the last three decades may have also played an important role in the catch levels, particularly in the case of $C$. falciformis. Quantitative population assessments of these species to determine the optimum levels of extraction in the region are urgently needed.
\end{abstract}

Key words: resilience, rebound potential, artisanal shark fishery, elasmobranchs.

RESUMEN. Dadas sus características biológicas, los tiburones exhiben baja resiliencia y por consecuencia, son considerados un recurso pesquero particularmente vulnerable a la sobrepesca. No obstante, durante varias décadas, tres especies de tiburón (Sphyrna lewini, Rhizoprionodon longurio y Carcharhinus falciformis) han contribuido de manera sostenida a las captura de la pesquería artesanal en la entrada del golfo de California, mostrando cierto grado de resiliencia. El objetivo de este estudio fue estimar la capacidad de estas especies para recuperarse de perturbaciones, con base en su potencial de recuperación $\left(r_{2 \mathrm{M}}\right)$, analizando los factores que pueden estar favoreciendo su capacidad de producir capturas aparentemente estables en la región. Para el presente análisis, se utilizó la información de captura y de composición de tallas tomada de muestreos biológicos realizados y de lo registrado en estudios previos, así como información publicada de los parámetros de historia de vida de estas especies. Rhizoprionodon longurio mostró productividad alta $\left(r_{2 \mathrm{M}}=0.083\right) \mathrm{y}$, por lo tanto, alta resiliencia, mientras que $C$. falciformis y $S$. lewini presentaron productividades medias $\left(r_{2 \mathrm{M}}=0.053\right.$ y 0.062 , respectivamente), pero escenarios alternos considerando la incertidumbre en los parámetros de historia de vida de C. falciformis y $S$. lewini los ubicaron en la categoría de productividad baja. Todas las especies presentaron productividad baja cuando se consideró un valor más conservador de mortalidad natural (e.g., $1.25 M$ ) para alcanzar el rendimiento máximo sostenido. Las capturas estuvieron dominadas por juveniles de S. lewini y adultos y preadultos de $R$. longurio y $C$. falciformis durante todo el periodo analizado; esto y su contribución constante a las capturas sugiere una aparente estabilidad poblacional. Tal estabilidad puede estar relacionada con la productividad biológica, elasticidad, amplia distribución, hábitos migratorios y segregación de tallas. Sin embargo, los cambios en esta pesquería durante las últimas tres décadas también pudieron haber desempeñado un papel importante en los niveles de captura, particularmente en el caso de C. flaciformis. Se necesitan urgentemente evaluaciones cuantitativas de las poblaciones de estas especies para determinar los niveles óptimos de extracción en la región.

Palabras clave: resiliencia, potencial de recuperación, pesquería artesanal de tiburón, elasmobranquios. 


\section{INTRODUCTION}

Resilience is the ability of a species to return to its original state after a change due to natural or human-caused disturbances (Doak et al. 1998). In fisheries science, resilience refers to the ability of stocks under exploitation to respond to fishing pressure, and simple methods, such as the rebound potential $\left(r_{2 \mathrm{M}}\right)$, have been developed to measure the relative ability of populations to recover from fishing pressure (Au and Smith 1997).

Apex predators, such as sharks, evolved under low natural mortality pressures in comparison to other fishes (Clarke et al. 2007). Consequently, it is believed that they present low resilience and their populations are more susceptible to overfishing or environmental degradation (Bonfil 1994, Castro et al. 1999, Fowler et al. 2005, Clarke et al. 2007). It has been estimated that during the last decades marine top predator populations have been reduced by at least one order of magnitude, mainly due to fishing pressure (Myers and Worm 2005). Furthermore, many regions around the world have registered a significant decrease in shark catches (Baum and Myers 2004, Shepherd and Myers 2005, Cortés et al. 2007) and there are still no reports about the recovery of any shark population after overexploitation.

Among sharks there is, however, a wide range of productive capacities, related to variation in their life-history characteristics (Walker 1998, Stevens et al. 2000). Such differences result in some species being more resilient to fishing pressure than others (Smith et al. 1998, Stevens et al. 2000). For example, the gummy shark, Mustelus antarcticus, considered a species with high biological productivity among sharks, have maintained sustainable catch levels under careful management schemes in Australia, whereas the school shark, Galeorhinus galeus, has decreased despite similar management schemes, probably due to its lower biological productivity (Walker 1998).

The region encompassing the entrance to the Gulf of California (GC), including the coastal waters of Nayarit and southern Sinaloa, as well as the surrounding waters of Isabel Island and the Marias Islands Archipelago, is one of the oldest and most traditional shark fishing regions in the Mexican Pacific. During at least seven decades an artisanal shark fishery has operated in this area, based on a large variety of sharks, some of high commercial importance (Pérez-Jiménez et al. 2005, Moncayo-Estrada et al. 2006, Torres-Herrera and Tovar-Ávila 2014).

Some studies have been carried out at the entrance to the GC to determine the composition of shark catches (SaucedoBarrón 1982, Soriano-Velásquez et al. 2005, Torres-Herrera and Tovar-Ávila 2014) and their relative abundance (PérezJiménez et al. 2005). However, the lack of information of landings by species in Mexico makes the use of quantitative methods to determine their population status and sustainable levels of exploitation difficult. Nevertheless, the comparison of the information reported in those studies might be useful to

\section{INTRODUCCIÓN}

Resiliencia es la habilidad de las especies para recuperarse después de un cambio debido a perturbaciones naturales o derivadas de actividades humanas (Doak et al. 1998). En la ciencia pesquera, la resiliencia se refiere a la capacidad de las poblaciones bajo explotación para sobreponerse a la presión pesquera, y se han desarrollado métodos sencillos, como el potencial de recuperación $\left(r_{2 \mathrm{M}}\right)$, para medir de una forma relativa la capacidad de recuperación de una población a la presión pesquera (Au y Smith 1997).

Los depredadores tope, como los tiburones, evolucionaron bajo presiones de mortalidad natural bajas en comparación con otros peces (Clarke et al. 2007). En consecuencia, se piensa que estos organismos presentan baja resiliencia y sus poblaciones son más susceptibles a la sobrepesca o degradación ambiental (Bonfil 1994, Castro et al. 1999, Fowler et al. 2005, Clarke et al. 2007). Se ha estimado que durante las últimas décadas las poblaciones de depredadores marinos tope se han reducido en al menos un orden de magnitud, debido principalmente a la presión pesquera (Myers y Worm 2005). Además, en muchas regiones alrededor del mundo se han registrado decrementos significativos en las capturas de tiburón (Baum y Myers 2004, Shepherd y Myers, 2005, Cortés et al. 2007), y a la fecha no hay reportes acerca de la recuperación de alguna población de tiburón después de una sobreexplotación.

Entre los tiburones, sin embargo, existe una amplia gama de capacidades productivas, relacionadas con variaciones en sus características de historia de vida (Walker 1998, Stevens et al. 2000). Tales diferencias repercuten en que algunas especies sean más resilientes a la presión pesquera que otras (Smith et al. 1998, Stevens et al. 2000). Por ejemplo, la musola suave, Mustelus antarcticus, considerada como una de las especies de tiburón con productividad biológica alta, ha mantenido niveles de captura sostenibles bajo cuidadosos esquemas de manejo en Australia, mientras que el tiburón vitamínico, Galeorhinus galeus, ha decrecido a pesar de esquemas similares de manejo, probablemente debido a su menor productividad biológica (Walker 1998).

La región que comprende la entrada del golfo de California (GC), incluyendo las aguas costeras de Nayarit y sur de Sinaloa, así como las aguas alrededor de la isla Isabel y el archipiélago de las islas Marías, es una de las más antiguas y tradicionales regiones de pesca de tiburón en el Pacífico mexicano. Durante al menos siete décadas, la pesquería artesanal de tiburón ha operado en esta área, donde se captura una gran variedad de tiburones, algunos de alto valor comercial (Pérez-Jiménez et al. 2005, MoncayoEstrada et al. 2006, Torres-Herrera y Tovar-Ávila 2014).

Algunos estudios se han llevado a cabo en la entrada del GC para determinar la composición específica de las capturas de tiburón (Saucedo-Barrón 1982, Soriano-Velásquez et al. 2005, Torres-Herrera y Tovar-Ávila 2014) y su abundancia relativa (Pérez-Jiménez et al. 2005). Sin embargo, la falta de 
detect negative impacts of the fishery, since changes in the species and length composition of catches can be used as indicators of the stability of a population (Wholfarth 1986, McAllister et al. 1992).

The possible extirpation of some shark species in the southern GC, for example the bonnethead shark, Sphyrna tiburo (described as abundant by Hernández-Carvallo in 1967), has been reported (Pérez-Jiménez 2014). However, shark catches in this area have remained significant during the last decades and have apparently increased during recent years in the central region of Nayarit (Torres-Herrera and Tovar-Ávila 2014). Over the past 30 years, Nayarit has contributed $879 \mathrm{t}$ (4.5\% of the total) per year on average to the Mexican Pacific shark production, and in 2011 the state contributed $1594 \mathrm{t}$, the highest level since 1981 (SEPESCA 1988; SEMARNAP 1998, 2004; SAGARPA 2012) (fig. 1).

Throughout the last three decades, shark landings of the artisanal fishery in Nayarit have been represented mainly by three species: the scalloped hammerhead shark, Sphyrna lewini (Griffith and Smith 1834), the Pacific sharpnose shark, Rhizoprionodon longurio (Jordan and Gilbert 1882), and the silky shark, Carcharhinus falciformis (Muller and Henle 1839) (Saucedo-Barrón 1982, Pérez-Jiménez et al. 2005, Soriano-Velásquez et al. 2005, Torres-Herrera and TovarÁvila 2014). These species have shown an apparent high resilience, since abundant harvest levels have been sustained for such an extended period.

The aim of the present study was to analyze the level of resilience of these three species, based on their rebound potential $\left(r_{2 \mathrm{M}}\right)$, estimated with new available information about their life history parameters in the region. Likewise, catch data collected during biological and fishery surveys, data reported in previous studies and information on the fishery were used to explain their apparent stability in catches.

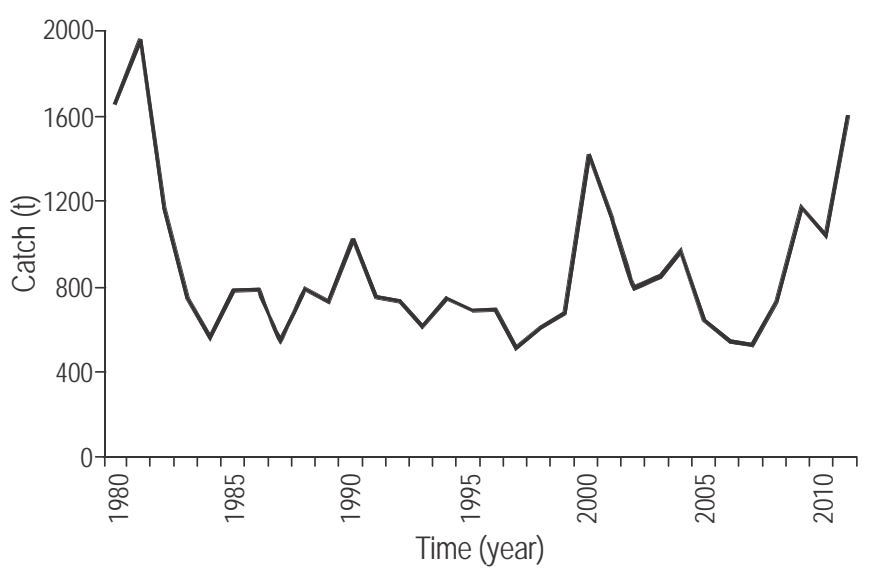

Figure 1. Historical shark catch in Nayarit (SEPESCA 1988; SEMARNAP 1998, 2004; SAGARPA 2012).

Figura 1. Captura histórica de tiburón en Nayarit (SEPESCA 1988; SEMARNAP 1998, 2004; SAGARPA 2012). información de las capturas por especie en México dificulta el uso de métodos cuantitativos para determinar el estado de las poblaciones y los niveles sostenibles de explotación. No obstante, la comparación de la información reportada en esos estudios puede ser útil para detectar impactos negativos de la pesquería, ya que los cambios en la composición específica y tallas de las capturas pueden utilizarse como indicadores de la estabilidad de una población (Wholfarth 1986, McAllister et al. 1992).

La posible extirpación de algunas especies de tiburón en el sur del GC, por ejemplo del tiburón cabeza de pala, Sphyrna tiburo (descrita como abundante por HernándezCarvallo en 1967), ha sido reportada (Pérez-Jiménez 2014). Sin embargo, los niveles de captura de tiburón en el área han permanecido altos durante las últimas décadas y aparentemente han incrementado en años recientes en la región central de Nayarit (Torres-Herrera y Tovar-Ávila 2014). La contribución de Nayarit a la producción de tiburón del Pacífico mexicano durante los últimos 30 años ha sido de $879 \mathrm{t}(4.5 \%$ del total) por año en promedio, y en 2011 este estado contribuyó con 1594 t, su nivel máximo desde 1981 (SEPESCA 1988; SEMARNAP 1998, 2004; SAGARPA 2012) (fig. 1).

A lo largo de las últimas tres décadas, los desembarques de tiburón de la flota artesanal de Nayarit han estado representados principalmente por tres especies: la cornuda común, Sphyrna lewini (Griffith y Smith 1834); el cazón bironche, Rhizoprionodon longurio (Jordan y Gilbert 1882); y el tiburón sedoso, Carcharhinus falciformis (Muller y Henle 1839) (Saucedo-Barrón 1982, Pérez-Jiménez et al. 2005, SorianoVelásquez et al. 2005, Torres-Herrera y Tovar-Ávila 2014). Las tres especies muestran una resiliencia aparentemente alta, en vista de los altos niveles de captura durante un periodo prolongado.

El objetivo de este estudio fue analizar el nivel de resiliencia de estas tres especies, con base en su potencial de recuperación $\left(r_{2 \mathrm{M}}\right)$, estimado con nueva información disponible sobre sus parámetros de historia de vida en la región. Asimismo, información de captura obtenida durante muestreos biológico-pesqueros, datos reportados en estudios previos e información de la pesquería fueron utilizados para explicar su aparente estabilidad en las capturas.

\section{MATERIALES Y MÉTODOS}

De marzo de 2007 a junio de 2010, se llevaron a cabo muestreos biológicos de los desembarques de la pesquería artesanal de tiburón en diversas localidades a lo largo de la costa de Nayarit (México). Los muestreos se realizaron mensualmente o cada dos meses en los principales sitios de desembarque de las tres localidades pesqueras más importantes (La Cruz de Huanacaxtle, San Blas e isla Isabel), y ocasionalmente en localidades más pequeñas o de menor importancia (La Peñita de Jaltemba, Chacala, Boca de Camichín y Boca del Asadero) en cuanto a los desembarques 


\section{MATERIALS AND METHODS}

\section{Data collection}

From March 2007 to June 2010, biological samplings of the artisanal shark fishery landings were conducted in several localities along the coast of Nayarit (Mexico). Samplings were carried out monthly or bimonthly in the three main fishing villages and landing sites (La Cruz de Huanacaxtle, San Blas, and Isabel Island), and occasionally in smaller or less important fishing villages (La Peñita de Jaltemba, Chacala, Boca de Camichín, and Boca del Asadero). Collected data were grouped into two main regions to facilitate the comparison with previous studies: (1) central Nayarit $(\mathrm{CN})$, including Isabel Island, San Blas, Boca del Asadero, and Boca de Camichín; and (2) southern Nayarit (SN), including La Cruz de Huanacaxtle, La Peñita de Jaltemba, and Chacala (fig. 2).

Shark species were identified according to Compagno et al. (1995) and Castro et al. (2002). All specimens were sexed and total length (TL) was measured when possible with a fiberglass tape to the nearest centimeter, from the tip of the nose to the end of the upper lobe of the caudal fin, with the caudal fin extended in the body axis (Compagno 2001). The TL of sharks landed beheaded was estimated from the alternative length (AL) (distance from the origin of the first dorsal fin base to the precaudal notch), by using the following relationships: Sphyrna lewini: $\mathrm{TL}=\mathrm{AL}(2.18)+5.157\left(r^{2}=\right.$ $0.95, n=163$ ) (Gallegos-Camacho and Tovar-Ávila 2011); Rhizoprionodon longurio: $\mathrm{TL}=\mathrm{AL}(1.99)+6.23\left(r^{2}=0.93\right.$, $n=87)$; and Carcharhinus falciformis: $\mathrm{TL}=\mathrm{AL}(2.29)+$ $10.50\left(r^{2}=0.95, n=391\right)$ (Ramírez-Santiago et al. 2006).

\section{Comparison of catch composition}

The percentage of each species in the catches, their size distribution, and the proportion of mature organisms (based on the reported length at maturity for each species) reported in previous studies in the region (Saucedo-Barrón 1982, Furlong-Estrada and Barragán-Cuencas 1997, Pérez-Jiménez and Venegas-Herrera 1997, Pérez-Jiménez 2001, SorianoVelásquez et al. 2005) were estimated and compared with those observed during the present study, to determine possible changes in the catch composition and thus in their population structure.

\section{Rates of population increase and rebound potential}

The intrinsic $(r)$ and finite $\left(\lambda=e^{r}\right)$ rates of population increase for the non-exploited populations were estimated for each species, using a simplified form of the Euler-Lotka equation (Au and Smith 1997):

$$
e^{-(Z+r)}=l_{a} b e^{-r a}\left[1-e^{-(Z+r)(w-a+1)}\right]=1.0
$$

de tiburón. Para facilitar la comparación con los estudios previos, los datos recolectados fueron agrupados en dos regiones: (1) Nayarit central (NC), que incluyó isla Isabel, San Blas, Boca del Asadero y Boca de Camichín; y (2) Nayarit sur (NS), que incluyó La Cruz de Huanacaxtle, La Peñita de Jaltemba y Chacala (fig. 2).

Las especies de tiburón fueron identificadas usando las guías de Compagno et al. (1995) y Castro et al. (2002). Todos los especímenes fueron sexados. Cuando fue posible se midió la longitud total (LT) con una cinta de fibra de vidrio al centímetro más cercano, de la punta de la nariz a la punta del lóbulo superior de la aleta caudal, extendida de acuerdo con el eje del cuerpo (Compagno 2001). La LT de los especímenes descargados sin cabeza fue estimada a partir de la longitud alternativa (LA) (distancia del origen de la primera aleta dorsal a la muesca precaudal) utilizando las siguientes ecuaciones: Sphyrna lewini: $\mathrm{LT}=\mathrm{LA}(2.18)+5.157$ $\left(r^{2}=0.95, n=163\right)$ (Gallegos-Camacho y Tovar-Ávila 2011); Rhizoprionodon longurio: LT $=\mathrm{LA}(1.99)+6.23\left(r^{2}=0.93\right.$, $n=87$ ); y Carcharhinus falciformis: LT $=\mathrm{LA}(2.29)+10.50$ ( $\left.r^{2}=0.95, n=391\right)$ (Ramírez-Santiago et al. 2006).

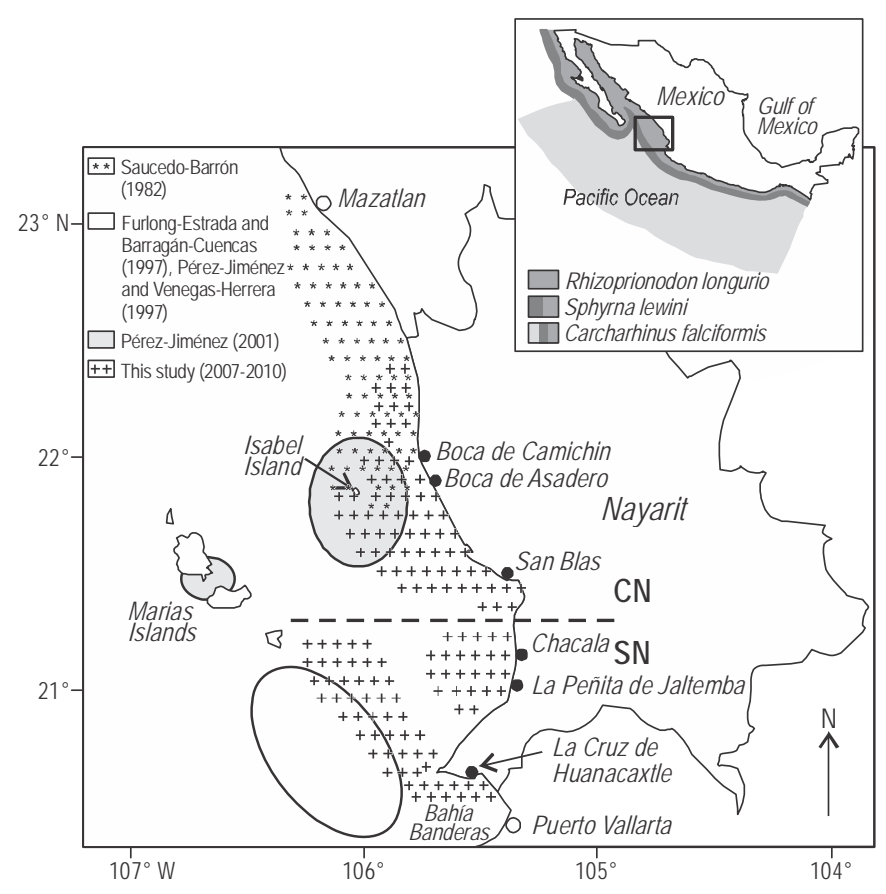

Figure 2. Localities (•) in Nayarit $(\mathrm{CN}$, central Nayarit; SN, southern Nayarit) sampled during the present study. Shark fishing zones reported in this and previous studies. The distribution of Rhizoprionodon longurio, Sphyrna lewini, and Carcharhinus falciformis in the Mexican Pacific (Compagno et al. 1995) is presented in the upper map.

Figura 2. Localidades muestreadas $(\bullet)$ en Nayarit $(\mathrm{CN}$, Nayarit central; SN, Nayarit sur) durante el presente estudio. Zonas de pesca de tiburón registradas en este estudio y en estudios previos. La distribución de Rhizoprionodon longurio, Sphyrna lewini y Carcharhinus falciformis en el Pacífico mexicano (Compagno et al. 1995) se presenta en el mapa superior. 
where $a$ is age at maturity, $w$ is maximum reproductive age, $l_{a}$ is survival to age $x, b$ is fecundity at age $x$ (annual newborn females per adult female), and $Z$ is total mortality, which equals natural mortality $(M)$ in an unfished population.

The rebound potential $\left(r_{2 \mathrm{M}}\right)$ was estimated in three consecutive steps (Au and Smith 1997). First, $r$ was determined for the unfished population with the previous equation. Second, preadult survival $\left(l_{a}\right)$ was estimated assuming that the maximum sustainable yield (MSY) is reached at $Z=2 M$ $\left(l_{a, 2 M}\right)$. Finally, $r_{2 \mathrm{M}}$ was obtained by removing the fishing pressure in population (returning $Z=M$ ) while retaining the increased value of $l_{a, 2 M}$. Two alternative scenarios were estimated using more conservative values of mortality necessary to achieve MSY (1.25M and 1.50M), which Simpfendorfer (2005) suggests are more likely for sharks.

The life history parameters of the species used in the modified version of the Euler Lotka equation were obtained from studies conducted in the GC or near the study area in their absence (table 1). $M$ for each species was estimated with the indirect method proposed by Hoenig (1983):

$$
\ln Z=1.46-1.01 \ln T_{\max }
$$

where $\mathrm{Z} \approx M$ and $T_{\max }$ is the maximum age in years.

This indirect method is the most widely used to estimate $M$ in shark species (Simpfendorfer 2005) and has also been used in ecological risk assessments of elasmobranchs (Braccini et al. 2006, Tovar-Ávila et al. 2010, FurlongEstrada et al. 2014).

The uncertainty in the life history parameters for C. falciformis and S. lewini was incorporated, in the case of fecundity, by using the average of the reported values, whereas in the case of age at maturity, maximum age, and the resulting $M$, uncertainty was incorporated using the maximum values reported, thus establishing an alternative scenario.

The productivity, and thus resilience, for each species was categorized as low $\left(r_{2 \mathrm{M}}<0.04\right)$, medium $\left(r_{2 \mathrm{M}}=0.04-0.07\right)$ or high $\left(r_{2 \mathrm{M}}>0.08\right)$, and compared with those reported previously by Smith et al. (1998) for the three species.

\section{RESULTS}

\section{Analysis of catch composition}

The proportion of landings sampled in each study was variable. Furlong-Estrada and Barragán-Cuencas (1997) and Pérez-Jiménez (2001) reported up to $80 \%$ of the total catch sampled in their studies, whereas Soriano-Velasquez et al. (2005) reported around 50\% of the landings recorded. Though Saucedo-Barrón (1982) did not present an estimation of the percentage of catches sampled, based on the description of the methodology it can be estimated that over $50 \%$ of landings were sampled. A lower coverage of total landings

\section{Comparación de la composición de la captura}

El porcentaje de cada especie en las capturas, su distribución de tallas y la proporción de organismos maduros (con base en la longitud de madurez reportada para cada especie) reportados en los estudios previos realizados en la región (Saucedo-Barrón 1982, Furlong-Estrada y Barragán-Cuencas 1997, Pérez-Jiménez y Venegas-Herrera 1997, Pérez-Jiménez 2001, Soriano-Velásquez et al. 2005) fueron estimados y comparados con aquellos observados durante el presente estudio, para determinar posibles cambios en la composición de las capturas y por tanto en la estructura poblacional.

\section{Tasas de incremento poblacional y potencial de recuperación}

Las tasas intrínseca $(r)$ y finita $\left(\lambda=e^{r}\right)$ de incremento poblacional para las poblaciones no explotadas fueron estimadas para cada especie, utilizando una forma simplificada de la ecuación de Euler-Lotka (Au y Smith 1997):

$$
e^{-(Z+r)}=l_{a} b e^{-r a}\left[1-e^{-(Z+r)(w-a+1)}\right]=1.0
$$

donde $\alpha$ es la edad de madurez, $w$ es la edad reproductiva máxima, $l_{\alpha}$ es la supervivencia a la edad $x, b$ es la fecundidad a la edad $x$ (en número de hembras nacidas anualmente por hembra adulta) y $Z$ es la mortalidad total, la cual equivale a la mortalidad natural $(M)$ en poblaciones no explotadas.

El potencial de recuperación $\left(r_{2 M}\right)$ fue estimado en tres pasos consecutivos (Au y Smith 1997). Primero, $r$ fue determinada para la población sin explotar con la ecuación antes señalada. Segundo, la supervivencia de los preadultos $\left(l_{\alpha}\right)$ fue estimada suponiendo que el rendimiento máximo sostenible (RMS) se alcanza a una $Z=2 M$. Finalmente, $r_{2 M}$ fue obtenida eliminando la presión pesquera de la población (retornando $Z=M$ ) pero conservando el incremento del valor de $l_{\alpha, 2 M}$. Dos escenarios alternos fueron estimados usando valores más conservadores de mortalidad necesaria para alcanzar el RMS (1.25M y $1.50 M)$, los cuales Simpfendorfer (2005) sugiere como más probables para los tiburones.

Los parámetros de historia de vida de las especies utilizados en la ecuación modificada de Euler-Lotka fueron obtenidos de estudios realizados en el GC o, en su ausencia, en áreas cercanas (tabla 1). La $M$ de cada especie fue estimada a través del método indirecto propuesto por Hoenig (1983):

$$
\ln Z=1.46-1.01 \ln T_{\max }
$$

donde $\mathrm{Z} \approx M \mathrm{y} \mathrm{T}_{\text {max }}$ es la edad máxima en años.

Este método indirecto es el más usado para estimar la $M$ de especies de tiburón (Simpfendorfer 2005) y ha sido utilizado también en evaluaciones de riesgo ecológico para elasmobranquios (Braccini et al. 2006, Tovar-Ávila et al. 2010, Furlong-Estrada et al. 2014). 
Table 1. Biological parameters reported for Sphyrna lewini, Rhizoprionodon longurio, and Carcharhinus falciformis in the Pacific Ocean: $s_{\alpha}$, size at maturity (cm); $w$, maximum age (years); $\alpha$, age at maturity (years); $F$, fecundity (average pups); $b$, average fecundity $/ 2$ (female pups per adult female); and $M$, natural mortality.

Tabla 1. Parámetros biológicos reportados para Sphyrna lewini, Rhizoprionodon longurio y Carcharhinus falciformis en el océano Pacífico. $s_{\alpha}$, talla de madurez (cm); $w$, edad máxima (años); $\alpha$, edad de madurez (años); $F$, fecundidad (promedio de crías); $b$, fecundidad promedio/2 (crías de hembra por hembra adulta); y $M$, mortalidad natural.

\begin{tabular}{|c|c|c|c|c|c|c|c|}
\hline Species & $s_{a}$ & $w$ & $a$ & $F$ & $b$ & $M$ & Reference \\
\hline C. falciformis & 182 & $16-31$ & $7.0-16.0$ & 5.0 & 2.50 & $0.13-0.26$ & $\begin{array}{l}\text { Sánchez de Ita et al. (2010), Hoyos-Padilla } \\
\text { et al. (2012), Mondragón-Sánchez (2015) }\end{array}$ \\
\hline
\end{tabular}

* Age estimates assuming the formation of two growth bands per year in the vertebrae (Anislado-Tolentino et al. 2008) and one growth band per year (Gallegos-Camacho 2009).

was estimated for the present study (approximately $25 \%$ ) due to the larger number of localities studied.

The previous studies were undertaken during the main shark fishing season in this region, which extends from the end of autumn to the end of spring (November to April). Though the present study included samplings performed in summer, most of the samples were obtained during the main fishing season, particularly during March in CN (58\%). Thus, it can be considered that the present study can be compared with the previous ones.

A total of 1082 sharks were sampled during 2007-2010. The shark landings were composed mainly of S. lewini, R. longurio and C. falciformis. In $\mathrm{CN}, 788$ sharks were recorded ( $73 \%$ of individuals recorded in all the localities), of which 381 corresponded to S. lewini (48\%) and 314 to R. longurio (40\%), representing together $88 \%$ of the total sharks recorded in CN. Similarly, both species made up $86 \%$ of the shark catches sampled in northern Nayarit, southern Sinaloa, and Isabel Island during the 1980-1981 fishing season (Saucedo-Barrón 1982), and 95\% of the Isabel Island shark catches sampled during the 2000-2001 fishing season (Pérez-Jiménez 2001).

In $\mathrm{SN}$, a total of 128 C. falciformis were recorded, representing the most abundant species (44\%) in the landings of this region. The number of $C$. falciformis recorded in previous studies was considerably higher, though their importance in the landings was similar. The species was the most abundant (49\%) in the catches landed at La Cruz de Huanacaxtle during $2004(n=379)$ (Soriano-Velasquez et al. 2005) (table 2), whereas during the 1995-1996 fishing season, it was the second most common $(27.5 \%)$ in the catches of the same locality, behind Sphyrna zygaena (35\%) ( $n=2004$ ) (Furlong-Estrada and Barragán-Cuencas 1997, Pérez-Jiménez and Venegas-Herrera 1997).

Almost all individuals (99\%) of $S$. lewini recorded in $\mathrm{CN}$ measured $<150 \mathrm{~cm}$ TL, lower than the size at maturity estimated for this species $(207 \mathrm{~cm} \mathrm{TL}$, Torres-Huerta et al.
La incertidumbre en los parámetros de historia de vida de C. falciformis y S. lewini fue incorporada, en el caso de la fecundidad, utilizando el promedio de los valores reportados, y en el caso de la edad máxima, edad de madurez y $M$ resultante, la incertidumbre se incorporó al utilizar los valores máximos reportados para establecer un escenario alterno.

La productividad, y por tanto la resiliencia, para cada especie fue categorizada como baja $\left(r_{2 M}<0.04\right)$, media $\left(r_{2 M}=0.04-0.07\right)$ o alta $\left(r_{2 M}>0.08\right)$, y comparada con aquellas registradas previamente por Smith et al. (1998) para las tres especies.

\section{RESULTADOS}

\section{Análisis de la composición de captura}

La proporción de los desembarques muestreados en cada estudio fue variable. Furlong-Estrada y BarragánCuencas (1997) y Pérez-Jiménez (2001) reportaron muestreos del $80 \%$ de la captura total en sus respectivos estudios, mientras que Soriano-Velásquez et al. (2005) registraron aproximadamente el 50\% de los desembarques. Aunque Saucedo-Barrón (1982) no precisa el porcentaje muestreado de las capturas, con base en su descripción metodológica se estima que la muestra fue de más del $50 \%$ del total de los desembarques de tiburón. Se estimó una menor cobertura de muestreo de los desembarques para el presente estudio (aproximadamente el 25\%) debido al mayor número de localidades estudiadas.

Los estudios previos fueron llevados a cabo durante la principal temporada de pesca de tiburón en la región, la cual ocurre de a finales del otoño a finales de la primavera (noviembre a abril). Aunque el presente estudio incluyó muestreos durante el verano, la mayoría de las muestras fueron obtenidas durante la temporada principal de pesca, 

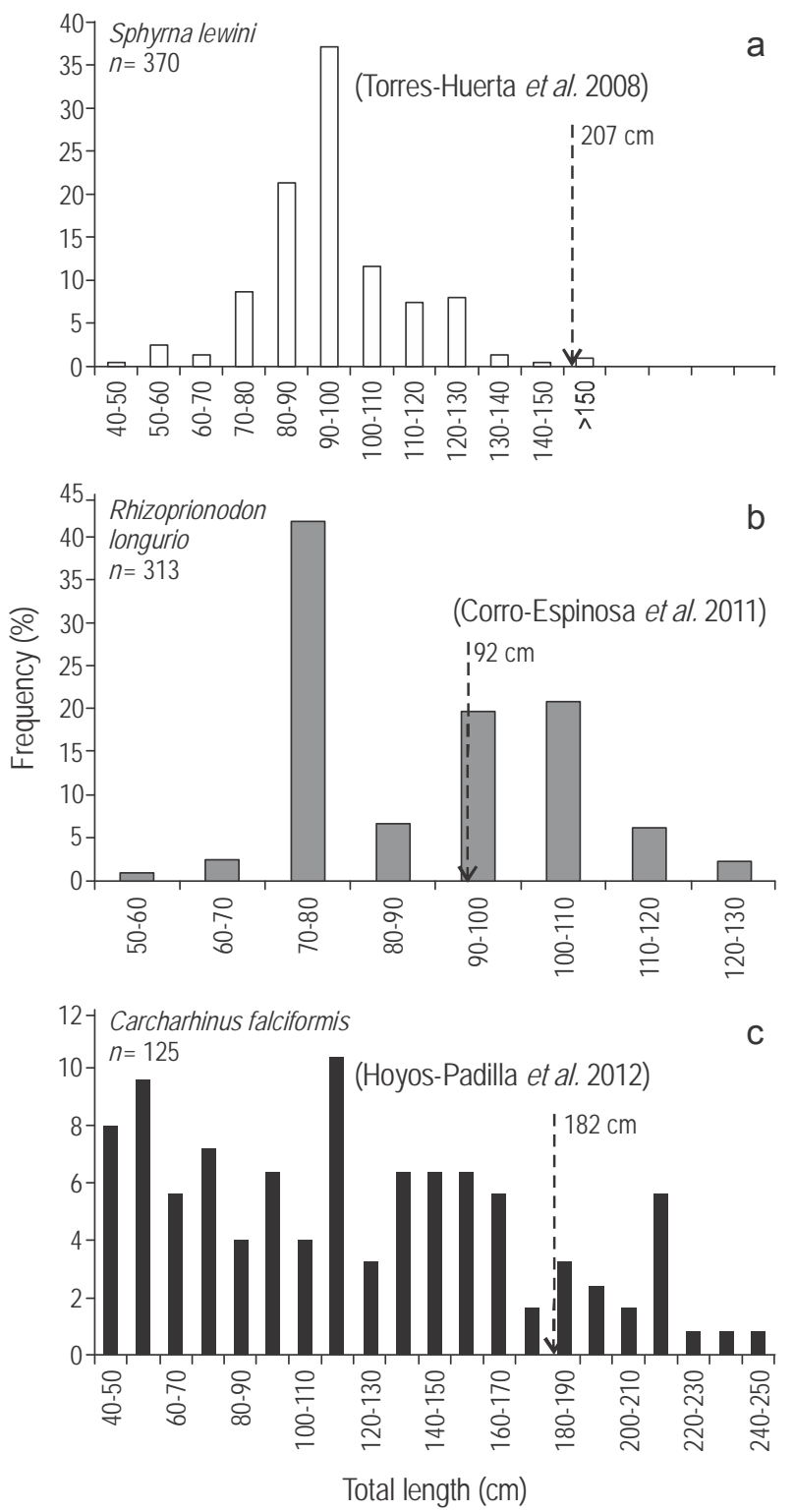

Figure 3. Length-frequency distribution of Sphyrna lewini (a) and Rhizoprionodon longurio (b) in central Nayarit and of Carcharhinus falciformis (c) in southern Nayarit, during the present study (2007-2010). Size at maturity reported for each species is represented by an arrow.

Figura 3. Distribución de frecuencias de longitud de Sphyrna lewini (a) y Rhizoprionodon longurio (b) en Nayarit central y de Carcharhinus falciformis (c) in Nayarit sur, durante el presente estudio (2007-2010). La talla de madurez reportada para cada especie está representada por la flecha.

2008), $66 \%$ of the specimens ranging from 75 to $105 \mathrm{~cm} \mathrm{TL}$ (fig. 3, table 2). On the other hand, $45 \%$ of $R$. longurio registered in $\mathrm{CN}$ had equal or greater TL than the size at maturity reported for the species $(92 \mathrm{~cm}$ TL, Corro-Espinosa et al. 2011 ) and $89 \%$ ranged from 70 to $110 \mathrm{~cm}$ TL (fig. 3, table 2). Similarly, a high percentage of juvenile $S$. lewini and preadult (sharks that are close to reaching the size at maturity) particularmente durante marzo en NC (58\%). Por lo tanto, se considera que el presente estudio puede ser comparado con los estudios señalados.

Un total de 1082 tiburones fueron muestreados durante 2007-2010. Los desembarques de tiburones estuvieron compuestos principalmente por $S$. lewini, $R$. longurio y C. falciformis. En NC se registraron 788 tiburones (73\% de los organismos registrados en todas las localidades), de los cuales 381 correspondieron a S. lewini $(48 \%)$ y 314 a R. longurio (40\%), representando en conjunto el $88 \%$ del total de la captura de tiburón en NC. De manera similar, estas dos especies compusieron el $86 \%$ de las capturas de tiburón muestreadas en el norte de Nayarit, sur de Sinaloa e isla Isabel durante la temporada de pesca 1980-1981 (SaucedoBarrón 1982), y el 95\% de las capturas de tiburón muestreadas en isla Isabel durante la temporada de pesca 2000-2001 (Pérez-Jiménez 2001).

En NS, se registró un total de 128 especímenes de C. falciformis, representando la especie de tiburón más abundante (44\%) en esta región. El número de C. falciformis registrado en estudios previos fue considerablemente mayor, aunque la proporción en los desembarques fue similar. En los desembarques de tiburón en La Cruz de Huanacaxtle, esta especie fue las más abundante (49\%) durante $2004(n=379)$ (Soriano-Velásquez et al. 2005) (tabla 2), mientras que durante la temporada de pesca 1995-1996, fue la segunda más frecuente (27.5\%), detrás de Sphyrna zygaena (35\%) $(n=2004)$ (Furlong-Estrada y Barragán-Cuencas 1997, Pérez-Jiménez y Venegas-Herrera 1997).

Casi el total (99\%) de los especímenes de S. lewini registrados en NC midieron $<150 \mathrm{~cm} \mathrm{LT}$, por debajo de la talla de madurez estimada para esta especie $(207 \mathrm{~cm} \mathrm{LT}$, TorresHuerta et al. 2008); 66\% de los especímenes midió entre 75 y $105 \mathrm{~cm} \mathrm{LT} \mathrm{(fig.} \mathrm{3,} \mathrm{tabla} \mathrm{2).} \mathrm{Por} \mathrm{otro} \mathrm{lado,} 45 \%$ de los especímenes de $R$. longurio registrados en NC tuvieron una LT igual o mayor que la talla de madurez reportada para la especie (92 cm LT, Corro-Espinosa et al. 2011), y 89\% midió entre 70 y $110 \mathrm{~cm} \mathrm{LT} \mathrm{(fig.} \mathrm{3,} \mathrm{tabla} \mathrm{2).} \mathrm{De} \mathrm{forma} \mathrm{similar,} \mathrm{un}$ alto porcentaje de juveniles de S. lewini y preadultos (organismos con talla cercana a la talla de madurez) de $R$. longurio fueron registrados en las capturas del norte de Nayarit, isla Isabel y sur de Sinaloa durante 1980-1981 (Saucedo-Barrón 1981) y de isla Isabel durante 2000-2001 (Pérez-Jiménez 2001) (tabla 2).

Un alto porcentaje $(85 \%)$ de los especímenes de C. falciformis registrados en la región NS midió menos que la talla de madurez reportada (182 cm LT, Hoyos-Padilla et al. 2012), y el 55\% de los especímenes midió entre 40 y $120 \mathrm{~cm}$ LT (fig. 3, tabla 2). Al contrario, un alto porcentaje (55\% y $40 \%$ ) de organismos maduros fueron registrados previamente en La Cruz de Huanacaxtle por Furlong-Estrada y BarragánCuencas (1997) y Soriano-Velásquez et al. (2005), respectivamente (tabla 2). 
Table 2. Relative abundance in the total catch, range of catch sizes and most common size range (centimeters of total length [TL]), and proportion of mature and immature organisms of Sphyrna lewini, Rhizoprionodon longurio, and Carcharhinus falciformis, as well as main fishing method used at the entrance to the Gulf of California recorded in the present and previous studies.

Tabla 2. Abundancia relativa en la captura total, intervalo de tallas de captura e intervalo de tallas más comunes (longitud total [TL] en centímetros), y proporción de organismos maduros e inmaduros de Sphyrna lewini, Rhizoprionodon longurio y Carcharhinus falciformis, así como los principales métodos de captura usados en la entrada del golfo de California, registrados en el presente estudio y en estudios previos.

\begin{tabular}{|c|c|c|c|c|c|c|}
\hline Species & $\begin{array}{c}\text { Abundance } \\
(\%)\end{array}$ & $\begin{array}{l}\text { Size range } \\
\quad(\mathrm{TL})\end{array}$ & $\begin{array}{l}\text { Common size } \\
\text { range (TL) }\end{array}$ & $\begin{array}{c}\text { Mature/immature } \\
\text { proportion }(\%)\end{array}$ & $\begin{array}{l}\text { Fishing } \\
\text { method }^{\mathrm{a}}\end{array}$ & Reference $^{b}$ \\
\hline \multirow[t]{3}{*}{ S. lewini } & 55 & $47-270$ & 69-134 & $10 / 90$ & BFL & 1 \\
\hline & 50 & $55-138$ & $75-100$ & $0 / 100$ & BFL, DL & 2 \\
\hline & 41 & $47-274$ & $70-105$ & $4 / 96$ & BFL & 5 \\
\hline \multirow[t]{3}{*}{ R. longurio } & 31 & $54-115$ & $54-95$ & Not reported & BFL & 1 \\
\hline & 45 & $62-127$ & $85-115$ & $21 / 79$ & BFL, DL & 2 \\
\hline & 33 & $45-125$ & $70-110$ & $46 / 54$ & BFL & 5 \\
\hline \multirow[t]{3}{*}{ C. falciformis } & 27 & $87-225$ & $160-210$ & $55 / 45$ & DG & 3 \\
\hline & 49 & $55-237$ & $180-210$ & $40 / 60$ & DL & 4 \\
\hline & 14 & $58-246$ & $70-110$ & $15 / 85$ & BFL & 5 \\
\hline
\end{tabular}

${ }^{a}$ BFL, bottom fixed longlines; DL, drift longlines; DG, drift gillnets.

b (1) Saucedo-Barrón (1982), (2) Pérez-Jiménez (2001), (3) Furlong-Estrada and Barragán-Cuencas (1997), (4) Soriano-Velásquez et al. (2005),

(5) present study.

Table 3. Intrinsic $(r)$ and finite $(\lambda)$ rates of population increase, rebound potential $\left(r_{2 \mathrm{M}}\right)$, and $r_{2 \mathrm{M}}$ category for Sphyrna lewini, Rhizoprionodon longurio, and Carcharhinus falciformis, estimated in the present study. The $r_{2 \mathrm{M}}$ reported by Smith et al. (1998) for the species is also presented.

Tabla 3. Tasas intrínseca $(r)$ y finita $(\lambda)$ de incremento poblacional, potencial de recuperación $\left(r_{2 \mathrm{M}}\right)$ y categorías de $r_{2 \mathrm{M}}$ de Sphyrna lewini, Rhizoprionodon longurio y Carcharhinus falciformis, estimados en el presente estudio. Los valores $r_{2 \mathrm{M}}$ reportados por Smith et al. (1998) para estas especies son también presentados.

\begin{tabular}{lccccc}
\hline Species & $r$ & $\lambda$ & $r_{2 \mathrm{M}}$ & $r_{2 \mathrm{M}}$ category & $r_{2 \mathrm{M}}($ Smith et al. 1998) \\
\hline & \multicolumn{5}{c}{ First scenario (lowest age at maturity and longevity) } \\
R. longurio & 0.213 & 1.240 & 0.083 & High & $0.084^{*}$ \\
C. falciformis & 0.072 & 1.070 & 0.053 & Medium & 0.043 \\
S. lewini & 0.299 & 1.340 & 0.062 & Medium & 0.028 \\
& \multicolumn{5}{c}{ Second scenario (highest age at maturity and longevity) } \\
C. falciformis & 0.059 & 1.060 & 0.023 & Low & 0.043 \\
S. lewini & 0.189 & 1.200 & 0.033 & Low & 0.028 \\
\hline
\end{tabular}

* Estimated value for the Atlantic sharpnose shark (Rhizoprionodon terraenovae).

R. longurio were recorded in the catches from northern Nayarit, Isabel Island, and southern Sinaloa during 1980-1981 (Saucedo-Barrón 1982) and from Isabel Island during 2000-2001 (Pérez-Jiménez 2001) (table 2).

A high percentage ( $85 \%$ ) of $C$. falciformis recorded in the SN region were smaller than the reported size at maturity (182 cm TL, Hoyos-Padilla et al. 2012), and 55\% of the specimens ranged from 40 to $120 \mathrm{~cm}$ TL (fig. 3, table 2). On the contrary, a high percentage (55\% and $40 \%$ ) of mature organisms were recorded previously in La Cruz de Huanacaxtle by Furlong-Estrada and Barragán-Cuencas (1997) and SorianoVelásquez et al. (2005), respectively (table 2).

\section{Tasas de incremento poblacional y potencial de recuperación}

Rhizoprionodon longurio presentó las tasas más altas de incremento poblacional y una mayor productividad $\left(r_{2 M}=\right.$ 0.83), mientras que $C$. falciformis y $S$. lewini presentaron tasas menores de incremento poblacional y valores de productividad medios $\left(r_{2 M}=0.053\right.$ y 0.062 , respectivamente) (tabla 3, fig. 4). Sin embargo, en el escenario alterno realizado para $C$. falciformis y $S$. lewini considerando el límite superior de las estimaciones de edad de madurez y longevidad, ambas especies descendieron a la categoría 
Furlong-Estrada et al.: Resilience of three shark species in the Gulf of California

\section{Rates of population increase and rebound potential}

Rhizoprionodon longurio presented the highest rates of population increase and a high productivity level $\left(r_{2 \mathrm{M}}=0.83\right)$, whereas $C$. falciformis and $S$. lewini presented lower rates of population increase and medium productivity $\left(r_{2 \mathrm{M}}=0.053\right.$ and 0.062 , respectively) (table 3 , fig. 4). However, in the alternative scenario performed for C. falciformis and S. lewini considering the upper limit of age at maturity and longevity estimates, both species descended to the low productivity category $\left(r_{2 \mathrm{M}}=0.023\right.$ for $C$. falciformis and $r_{2 \mathrm{M}}=0.033$ for $S$. lewini) (fig. 4).

All species descended in their productivity category in the alternative scenarios considering lower $M$ to achieve MSY $(1.50$ and $1.25 M)$. In the $1.50 M$ scenario, $R$. longurio descended to the medium category and the other species descended to the low resilience category, whereas in the $1.25 \mathrm{M}$ scenario all species were placed in the low category (fig. 4).

\section{DISCUSSION}

Over the past decades, the three shark species analyzed, along with the blue shark (Prionace glauca), have been the most frequent sharks in the artisanal landings along the Mexican Pacific coast and have contributed substantially to support this activity (CONAPESCA-INP 2004). Catches of S. lewini, R. longurio, and C. falciformis are important from Sinaloa to the southern Mexican Pacific, but they are rather sporadic in the central and northern GC (Bizzarro et al. 2009a, Smith et al. 2009).

Sphyrna lewini is perhaps the most important shark species in catches in several regions of the Mexican Pacific, such as the central region (states of Jalisco, Colima, Michoacán. and Guerrero) (Madrid et al. 1997, Anislado-Tolentino and Robinson-Mendoza 2001). In the southern Mexican Pacific this species is also an important component of the artisanal landings; for example, in Oaxaca it contributed 64\% of the shark catch recorded from September 2004 to June 2006 $(n=1233)$ (Bejarano-Álvarez et al. 2010), and in Chiapas it was the second most common shark, representing $29 \%$ of the total catch $(n=37,669)$ during 1996-2003 (SorianoVelásquez et al. 2006).

Rhizoprionodon longurio is an important component of the catches of the artisanal shark fishery in Mazatlán, Sinaloa (Márquez-Farías et al. 2005). This small coastal shark is of great commercial value to many coastal communities of southern Sinaloa and Nayarit (Corro-Espinosa et al. 2011). Although its geographical distribution reaches the coast of Peru (Compagno 1999), apparently it is not an important fishery resource outside the GC.

Carcharhinus falciformis represents an important species for the shark fisheries in the central and southern Mexican Pacific. In Chiapas it represented $60 \%$ of the total shark catch during 1996-2003 (Soriano-Velásquez et al. 2006) and in

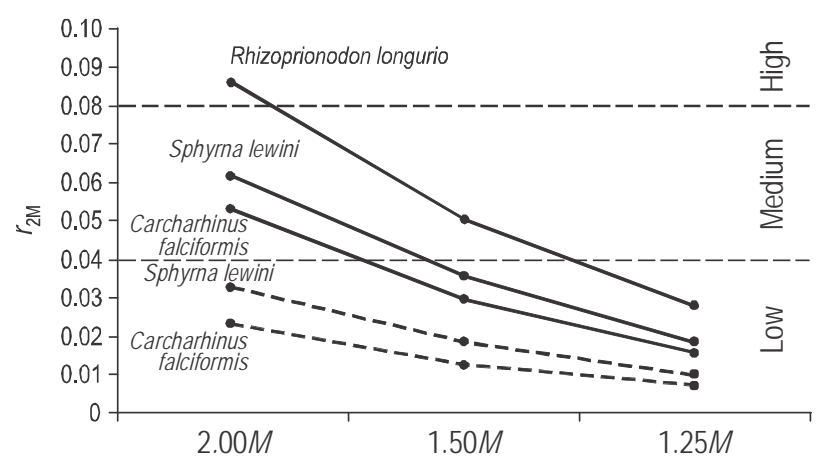

Figure 4. Rebound potential $\left(r_{2 \mathrm{M}}\right)$ for Rhizoprionodon longurio, Sphyrna lewini, and Carcharhinus falciformis using different values of mortality to achieve maximum sustainable yield. The dotted line represents the alternative scenarios for $C$. falciformis and $S$. lewini obtained with the upper maximum age limit and age at maturity estimated.

Figura 4. Potencial de recuperación $\left(r_{2 \mathrm{M}}\right)$ para Rhizoprionodon longurio, Sphyrna lewini y Carcharhinus falciformis usando diferentes valores de mortalidad para alcanzar el rendimiento máximo sostenible. La línea punteada representa los escenarios para $C$. falciformis y $S$. lewini obtenidos con el límite superior de las estimaciones de edad de madurez y edad máxima.

de productividad baja $\left(r_{2 M}=0.023\right.$ para $C$. falciformis y $r_{2 \mathrm{M}}=0.033$ para S. lewini) (fig. 4).

Todas las especies descendieron en la categoría de productividad en los escenarios alternos considerando una $M$ menor para alcanzar el RMS (1.50 y $1.25 M)$. En el escenario de $1.50 M, R$. longurio descendió a la categoría media y las dos especies restantes descendieron a la categoría de resiliencia baja, mientras que en el escenario de $1.25 \mathrm{M}$ las tres especies se ubicaron en la categoría baja (fig. 4).

\section{DISCUSIÓN}

Durante las últimas décadas, las tres especies analizadas, junto con el tiburón azul (Prionace glauca), han sido las especies de tiburón más frecuentes en las capturas de la pesquería artesanal a lo largo de la costa del Pacífico mexicano y han contribuido sustancialmente a sostener esta actividad (CONAPESCA-INP 2004). Las capturas de $S$. lewini, $R$. longurio y $C$. falciformis son importantes desde Sinaloa hasta el sur de la costa mexicana del Pacífico, pero son esporádicas en el centro y norte del GC (Bizarro et al. 2009a, Smith et al. 2009).

Sphyrna lewini es quizás la especie de tiburón más importante en las capturas en varias regiones del Pacífico mexicano, como en la región central (estados de Jalisco, Colima, Michoacán y Guerrero) (Madrid et al. 1997, Anislado-Tolentino y Robinson-Mendoza 2001). En el sur del Pacífico mexicano, esta especie es también un componente importante de los desembarques de la flota artesanal; por ejemplo, en Oaxaca, contribuyó con $64 \%$ de las 
Oaxaca it accounted for $36 \%$ of the shark landings during 2004-2005 $(n=1187)$ (Alejo-Plata et al. 2006). Additionally, it contributes significantly to the catches of the semi-industrial fleet operating in the central Mexican Pacific, representing $88 \%$ of the landings during 2006-2007 $(n=1962)$ (Cruz et al. 2011) and $53 \%$ of the catches of longline vessels during 2003-2011 (Santana-Hernández and Flores-Valdez 2013).

The analyzed species are widely distributed at the entrance to the GC (Compagno et al. 1995) (fig. 2), though S. lewini shows a marked coastal behavior and is usually common between 0 and $30 \mathrm{~m}$ depth (Compagno et al. 1995), thus easily reached by the fishing gear used by the artisanal shark fishery (longlines and nets). In the coastal waters of southern Sinaloa and northern Nayarit, catches of the artisanal fishery are composed of a high proportion of juvenile S. lewini during certain times of the year (Saucedo-Barrón 1982, Pérez-Jiménez et al. 2005, Torres-Huerta et al. 2008). The species is also commonly caught as by-catch in the trawl shrimp fishery in the region.

Rhizoprionodon longurio is a small shark with coastal habits, commonly found near the surface $(0-30 \mathrm{~m}$ depth). This species has been catalogued as the most abundant coastal shark in certain areas of the GC (Compagno et al. 1995). The predominance of pre-adults (close to reaching the size at maturity) and adults in catches is probably due to their size and to the hook size and mesh size of nets used by the artisanal fishery, which increase its catch susceptibility (Furlong-Estrada et al. 2014).

Carcharhinus falciformis was an important species for the La Cruz de Huanacaxtle (SN) fishery two decades ago, when large specimens were captured mainly offshore, to the south of the Marías Islands Archipelago (Pérez-Jiménez et al. 2005). Nowadays, due to the increase in fishing trip costs, shark fishing is conducted mainly in coastal waters, where juveniles may occur, and fishing in offshore areas is rather sporadic (Furlong-Estrada et al. 2014). This could explain, in part, the variation in the abundance and size of the silky shark recorded in the present and previous studies. Other factors affecting its distribution, such as oceanographic conditions or oceanographic anomalies like El Niño/Southern Oscillation, climate change, and marine pollution, may also be playing an important role in its abundance in the landings (Dulvy et al. 2003).

The $r_{2 \mathrm{M}}$ values for $R$. longurio estimated in the present study were similar to those reported by Smith et al. (1998), though the information used by Smith et al. (1998) corresponds to another species of the same genus (Rhizoprionodon terraenovae) due to lack of biology data at that time. New available information (Pérez-Jiménez et al. 2005, MárquezFarías et al. 2005, Castro 2009, Corro-Espinosa et al. 2011) has confirmed, however, that some biological characteristics of $R$. longurio in the southern $\mathrm{GC}$ are similar to those estimated for $R$. terraenovae in the Gulf of Mexico (Márquez-Farías and Castillo-Géniz 1998) and R. taylori in capturas de tiburón registradas durante septiembre de 2004 hasta junio de $2006(n=1233)$ (Bejarano-Álvarez et al. 2010), mientras que en Chiapas fue el segundo tiburón más común y contribuyó con el $29 \%$ de la captura total $(n=37,669)$ durante 1996-2003 (Soriano-Velásquez et al. 2006).

Rhizoprionodon longurio es un componente importante de las capturas de la pesquería artesanal en Mazatlán, Sinaloa (Márquez-Farías et al. 2005). Este pequeño tiburón costero tiene gran importancia comercial para muchas comunidades costeras del sur de Sinaloa y Nayarit (Corro-Espinosa et al. 2011). Aunque su distribución geográfica alcanza la costa del Perú (Compagno 1999), aparentemente su importancia pesquera fuera de la entrada del GC no es muy notable.

Carcharhinus falciformis representa también una especie importante para las pesquerías de tiburón en el centro y sur del Pacífico mexicano. En Chiapas representó 60\% de la captura total de tiburón durante 1996-2003 (Soriano-Velásquez et al. 2006), y en Oaxaca representó $36 \%$ de los desembarques de tiburón durante 2004-2005 $(n=1187)$ (Alejo-Plata et al. 2006). Además, C. falciformis contribuye significativamente a las capturas de la flota semi-industrial que opera en el Pacífico central mexicano, representando el $88 \%$ de los desembarques durante 2006-2007 $(n=1962)$ (Cruz et al. 2011) y el 53\% de las capturas de la flota palangrera durante 2003-2011 (Santana-Hernández y Flores-Valdez 2013).

Las especies analizadas están ampliamente distribuidas en la entrada del GC (Compagno et al. 1995) (fig. 2); no obstante, $S$. lewini muestra hábitos notablemente costeros y usualmente se encuentran entre los $0-30 \mathrm{~m}$ de profundidad (Compagno et al. 1995), por lo que puede ser fácilmente alcanzado por los sistemas de captura utilizados por la pesquería artesanal (palangres y redes). En las aguas costeras del sur de Sinaloa y norte de Nayarit, las capturas de la pesquería artesanal están compuestas por un gran número de juveniles de $S$. lewini durante cierta temporada del año (Saucedo-Barrón 1892, Pérez-Jiménez et al. 2005, TorresHuerta et al. 2008). Esta especie es también capturada comúnmente de manera incidental por la pesquería de arrastre de camarón en la región.

Rhizoprionodon longurio, es un tiburón pequeño de hábitos costeros, comúnmente encontrado cerca de la superficie (0-30 m de profundidad). Esta especie ha sido catalogada como el tiburón costero más abundante en ciertas áreas del GC (Compagno et al. 1995). La predominancia de preadultos (cerca de la talla de madurez) y adultos en las capturas se debe probablemente al tamaño de los anzuelos y luz de malla de las redes que utiliza la pesquería artesanal y que incrementan su susceptibilidad de captura (Furlong-Estrada et al. 2014).

Carcharhinus falciformis fue una especie importante para la pesquería de La Cruz de Huanacaxtle (en NS) hace dos décadas, cuando se capturaban grandes especímenes principalmente lejos de la costa, en el sur del archipiélago de las islas Marías (Pérez-Jiménez et al. 2005). En la actualidad, 
Furlong-Estrada et al.: Resilience of three shark species in the Gulf of California

northern Australia (Simpfendorfer 1999). These species are characterized as having a small size, rapid growth, early sexual maturity, and short gestation period and ovarian cycle, which would explain their relatively high biological productivity among sharks.

Noticeable changes in the abundance of $R$. longurio in the catches from one year to another have been observed by fishermen themselves. This could be related to hitherto unknown migration patterns of this species. Carlson et al. (2008) reported a wide range of movements (more than $399 \mathrm{~km}$ ) for juveniles of $R$. terraenovae, including incursions into deeper water, without a preference for a specific area. As its Atlantic congener, $R$. longurio could have a similar migratory behavior, which would help to explain its partial absence during some fishing seasons and would also act in favor of its resilience by reducing its catch susceptibility. Further research on the migratory routes of this and other shark species is urgently needed.

The $r_{2 \mathrm{M}}$ estimated for $S$. lewini was higher than that reported by Smith et al. (1998). However, in the alternative scenario using a higher age at maturity and maximum age, the productivity decreased to the low category. Such uncertainty in life history parameters is mainly due to the interpretation of the periodicity of vertebral growth band formation (one or two per year), and the consequent effect of agerelated parameters in the model used. Until validation studies are performed on this species, such uncertainty will persist, but a precautionary approach would suggest considering the lowest productivity, which represents a higher risk for their population to fishing pressure.

Currently, artisanal shark fishing in the studied area occurs predominantly in coastal waters, where most juvenile S. lewini are caught, due to the distribution of the species and limited range of operation of the fishing fleet. Simpfendorfer (1999) showed that in the dusky shark, Carcharhinus obscurus (species with biological and life history characteristics comparable to $S$. lewini), survival of neonates ( $0-1$ years of age) has relatively little influence on the intrinsic rate of increase $(r)$, whereas the survival of preadults and adults is critical for maintenance of the population. Consequently, the relatively low fishing pressure on adult $S$. lewini in comparison to the juveniles at the entrance to the GC has maybe acted inadvertently in favor of the population stability.

Age and growth studies on C. falciformis conducted in the Pacific Ocean (Joung et al. 2008, Sánchez de Ita et al. 2010) agree that the species has slow growth and late sexual maturity, approaching seven to eight years of age. However, a recent age analysis of this species conducted at the entrance to the GC suggests the possibility of an older age at maturity and maximum age than that previously reported (Mondragón-Sánchez 2015). The alternative scenario estimated with these parameters placed the species in the low $r_{2 \mathrm{M}}$ category, indicating a diminished capacity to recover and thus the need for careful management measures. debido al incremento en los costos de viaje, la pesca de tiburón se realiza principalmente en aguas costeras, donde se encuentran organismos juveniles, y la pesca en aguas lejanas se ha vuelto ocasional (Furlong-Estrada et al. 2014). Esto explica, en parte, la variación en la abundancia y talla observada entre los estudios previos y el presente. Otros factores que afectan su distribución, como las condiciones o anomalías oceanográficas como El Niño/Oscilación del Sur (ENOS), el cambio climático y la contaminación marina, pueden estar jugando también un papel importante en su abundancia en los desembarques (Dulvy et al. 2003).

Los valores de $r_{2 M}$ estimados para $R$. longurio en el presente estudio fueron similares a los registrados por Smith et al. (1998), aunque la información utilizada por Smith et al. (1998), provino de otra especie del mismo género (Rhizoprionodon terraenovae) debido a la falta de información biológica en ese tiempo. Nueva información disponible (Pérez-Jiménez et al. 2005, Márquez-Farías et al. 2005, Castro 2009, Corro-Espinosa et al. 2011) ha confirmado, sin embargo, que algunas características biológicas de $R$. longurio en el sur del GC son similares a quellas estimadas para $R$. terraenovae en el golfo de México (Márquez-Farías y Castillo-Géniz 1998) y $R$. taylori en el norte de Australia (Simpfendorfer 1999). Estas especies se caracterizan por su talla pequeña, crecimiento rápido, madurez temprana y cortos periodos de gestación y ciclo ovárico, que explicaría su productividad biológica relativamente alta entre los tiburones.

Cambios notables en la abundancia de las capturas de $R$. longurio entre un año y otro han sido observados por los pescadores mismos. Esto podría estar relacionado con los patrones migratorios de esta especie hasta ahora desconocidos. Carlson et al. (2008) registró movimientos de distancias largas (más de $399 \mathrm{~km}$ ) para juveniles de $R$. terraenovae, incluyendo incursiones hacia aguas profundas, sin una preferencia a un área determinada. Como su congénere del Atlántico, $R$. longurio pudiera tener un comportamiento migratorio similar, el cual podría explicar sus ausencias parciales en algunas temporadas de pesca y puede también actuar a favor de su resiliencia al disminuir su susceptibilidad de captura. Investigaciones sobre las rutas migratorias de esta y otras especies de tiburón son urgentemente necesarias.

El $r_{2 M}$ estimado para $S$. lewini, fue mayor al reportado por Smith et al. (1998). Sin embargo, en el escenario alterno, utilizando el límite superior de las estimaciones de edad de madurez y edad máxima, la productividad descendió a la categoría baja. Tal incertidumbre en los parámetros relacionados con la edad se debe principalmente a la interpretación de la periodicidad en la formación de bandas de crecimiento en las vértebras (una o dos por año), y el consecuente efecto de los parámetros relacionados con la edad en el modelo utilizado. Hasta que se realicen estudios de validación en esta especie, esta incertidumbre persistirá, pero el principio precautorio sugeriría considerar la productividad más baja, el cual representa un mayor riesgo de sus poblaciones a la presión pesquera. 
During the 1980s and 1990s, sharks were fished intensively in the Mexican Pacific, including the entrance to the GC, by an artisanal fleet from Chiapas, which followed their migration route (Pérez-Jiménez et al. 2005). Carcharhinus falciformis was one of the shark species most appreciated by these fishermen and the catches were mainly formed by adult organisms (Furlong-Estrada and Barragan-Cuencas 1997). This fleet disappeared in the early 2000s (Bizzarro et al. 2009b), probably due to a decrease in yields caused by the reduction of some shark populations. It is likely that the current stability of $C$. falciformis catches is also associated with a decrease in fishing pressure on breeding adults.

The $1.50 \mathrm{M}$ and $1.25 \mathrm{M}$ scenarios, considered to be more consistent with the biological characteristics of shark species, indicate that all the species analyzed have low productivity and that their populations are unable to support an intense exploitation scheme. Only $R$. longurio could present a medium productivity and hypothetically be able to sustain a directed fishery, but still careful management measures should be implemented.

The consistent catch proportions of these three shark species over the last three decades, as well as the stability of landings in Nayarit, suggests an apparent stability of their populations. However, stability might be related to certain features of the artisanal fishery operating in this area that have inadvertently contributed to the maintenance of catches.

In conclusion, according to the landings and catch composition, these three shark species still show signs of stability at the entrance to the GC. In the case of S. lewini and C. falciformis, it is likely that changes in the fishery may be playing a more important role in their apparent stability, as their life history characteristics (resilience ability) provide them with low biological productivity. In the case of $R$. longurio, however, the life history characteristics provide it with a higher biological productivity and thus may play an important role in its resilience. Enforcement of management measures, such as the recent temporal no fishing period (Diario Oficial de la Federación, Mexico, 11 June 2012) established in Mexican waters to protect some shark species during their breeding season, is necessary. Moreoever, research on catch trends and abundance indices is urgently needed to determine the optimum levels of extraction in the region.

\section{ACKNOWLEDGMENTS}

This study was supported by the National Fisheries Institute (INAPESCA) of Mexico. The senior author was supported by the National Council of Science and Technology (CONACYT, Mexico) through a doctoral fellowship. We thank the valuable comments of Elizabeth Brooks to improve the manuscript.
Actualmente, la pesca artesanal de tiburón en el área de estudio se realiza predominantemente en aguas costeras, donde la mayoría de juveniles de $S$. lewini son capturados, debido a la distribución de esta especie y al limitado radio de operaciones de la flota artesanal. Simpfendorfer (1999) mostró que la supervivencia de neonatos (edad 0-1 años) de Carcharhinus obscurus (una especie con historia de vida similar a $S$. lewini) tiene relativamente poca influencia en la tasa intrínseca de incremento poblacional $(r)$, mientras que la supervivencia de los preadultos y adultos es crítica para el mantenimiento de la población. Consecuentemente, la relativa baja presión pesquera sobre los adultos de S. lewini en comparación con los juveniles en la entrada del GC ha actuado tal vez de manera inadvertida en favor de la estabilidad poblacional.

Algunos estudios de edad y crecimiento en C. falciformis realizados en el océano Pacífico (Joung et al. 2008, Sánchezde Ita et al. 2010) concuerdan que esta especie tiene un crecimiento lento y madurez sexual tardía, que se aproxima a los siete u ocho años de edad. Sin embargo, un análisis reciente de la edad de esta especie realizado en la entrada del GC sugiere la posibilidad de que su edad de madurez y edad máxima sean mayores que las previamente reportadas (Mondragón-Sánchez 2015). El escenario alterno estimado con estos parámetros ubicó a la especie en la categoría $r_{2 M}$ baja, lo cual indica una disminuida capacidad de recuperación y que la especie requiere de cuidadosas medidas de manejo.

Durante las décadas de 1980 y 1990, una flota pesquera artesanal proveniente de Chiapas capturó intensivamente tiburones a lo largo de la costa del Pacífico mexicano, incluyendo la entrada del GC, siguiendo su migración (PérezJiménez et al. 2005). Carcharrhinus falciformis fue una de las especies más apreciadas por estos pescadores, y las capturas estaban conformadas principalmente por organismos adultos (Furlong-Estrada y Barragán-Cuencas 1997). Esta flota desapareció a principios de la década del 2000 (Bizarro et al. 2009b), probablemente debido a la disminución en el rendimiento causada por la reducción de algunas poblaciones de tiburón. Es probable que la actual estabilidad en las capturas de C. falciformis también este asociada con el decremento de la presión pesquera sobre los adultos reproductores.

Los escenarios $1.50 M$ y $1.25 M$, señalados como más acordes con las características biológicas de los tiburones, indican que todas las especies analizadas tienen una baja productividad y sus poblaciones son incapaces de soportar un régimen de explotación intensa. Sólo $R$. longurio presentaría una productividad media e hipotéticamente sería capaz de sostener una pesquería dirigida, pero aun así deben implementarse medidas de manejo cuidadosas.

La consistencia en la proporción de captura de estas tres especies en las últimas tres décadas, así como la estabilidad de los desembarques en Nayarit, sugiere una aparente estabilidad en sus poblaciones. Sin embargo, la estabilidad también 
Furlong-Estrada et al.: Resilience of three shark species in the Gulf of California

\section{REFERENCES}

Alejo-Plata C, Medina-González G, Cerdenares G. 2006. La pesca de tiburón en la costa chica de Oaxaca, México, 2000-2003. In: Salas S, Cabrera MA, Ramos J, Flores D, Sánchez J (eds.), Memorias de la Primera Conferencia de Pesquerías Costeras en Latinoamérica y el Caribe: Evaluando, Manejando y Balanceando Acciones, EPOMEX, México, pp. 22-38.

Anislado-Tolentino V, Robinson-Mendoza C. 2001. Age and growth of the scalloped hammerhead shark, Sphyrna lewini (Griffith and Smith 1834), along the central Pacific coast of Mexico. Cienc. Mar. 27: 501-520.

Anislado-Tolentino V, Gallardo-Cabello M, Amezcua-Linares F, Robinson-Mendoza C. 2008. Age and growth of the scalloped hammerhead shark, Sphyrna lewini (Griffith \& Smith 1834), from the southern coast of Sinaloa, Mexico. Hidrobiológica 18: $31-40$.

Au DW, SE Smith. 1997. A demographic method with population density compensation for estimating productivity and yield per recruit of the leopard shark (Triakis semifasciata). Can. J. Fish. Aquat. Sci. 54: 415-420.

Baum JK, Myers RA. 2004. Shifting baselines and the decline of pelagic sharks in the Gulf of Mexico. Ecol. Lett. 7: 135-145.

Bejarano-Álvarez M, Galván-Magaña F, Ochoa-Báez RI. 2010. Reproductive biology of the scalloped hammerhead shark Sphyrna lewini (Chondrichthyes: Sphyrnidae) off south-west Mexico. Aqua Int. J. Ichthyol. 17: 11-22.

Bizzarro JJ, Smith WD, Castillo-Géniz L, Ocampo-Torres A, Márquez-Farías JF, Heuter RE. 2009a. The seasonal importance of small coastal sharks and rays in the artisanal elasmobranch fishery of Sinaloa, Mexico. Pan-Am. J. Aquat. Sci. 4: 513-531.

Bizzarro, JJ, Smith WD, Márquez-Farías JF, Tyminski J, Hueter RE. $2009 \mathrm{~b}$. Temporal variation in the artisanal elasmobranch fishery of Sonora, Mexico. Fish. Res. 97: 103-117.

Bonfil R. 1994. Overview of world elasmobranch fisheries. FAO Fish. Tech. Pap. 341: 119 pp.

Braccini JM, Gillanders BM, Walker TI. 2006. Hierarchical approach to the assessment of fishing effects on non-target chondrichthyans: Case study of Squalus megalops in southeastern Australia. Can. J. Fish. Aquat. Sci. 63: 2456-2466.

Carlson JK, Heupel MR, Bethea DM, Hollensead LD. 2008. Coastal habitat use and residency of juvenile Atlantic sharpnose sharks (Rhizoprionodon terraenovae). Estuaries Coasts 31: 931-940.

Castro JI. 2009. Observations on the reproductive cycles of some viviparous North American sharks. Aqua Int. J. Ichthyol. 15: 205-222.

Castro JI, Woodley CM, Brudek RL. 1999. A preliminary evaluation of the status of shark species. FAO Fish. Tech. Pap. 380: 72 pp.

Castro JI, Castillo-Géniz L, Márquez-Farías JF. 2002. Guía para la identificación de las especies de tiburones de importancia comercial en el océano Pacífico. II ed. Secretaría de Agricultura, Ganadería Desarrollo Rural, Pesca y Alimentación, México.

Clarke SC, Milner-Gulland EJ, Bjorndal T. 2007. Social, economic and regulatory drivers of the shark fin trade. Mar. Resour. Econ. 22: $305-327$.

Compagno L. 1999. Checklist of living elasmobranchs. In: Hamlett WC (ed.), Sharks, Skates and Rays: The Biology of Elasmobranch Fishes. Johns Hopkins University Press, Baltimore, MD, pp. 471-498.

Compagno L. 2001. Sharks of the world. An annotated and illustrated catalogue of sharks species known to date. Vol. 2. Bullhead, mackerel, and carpet sharks (Heterodontiformes, Lamniformes and Orectolobiformes). FAO Species Catalogue for Fishery Purposes. No. 1, Vol. 2 Roma, FAO. 269 pp. podría relacionarse con ciertos aspectos de la pesquería artesanal que opera en esta área y que inadvertidamente han contribuido en el mantenimiento de las capturas.

En conclusión, de acuerdo con los desembarques y la composición de la captura, estas tres especies de tiburones siguen mostrando signos de estabilidad en la entrada del GC. En el caso de $S$. lewini y $C$. falciformis, es probable que los cambios en la pesquería jueguen inadvertidamente un papel más importante en su aparente estabilidad, puesto que sus características de historia de vida (capacidad de resiliencia) les proveen de una baja productividad biológica. Pero en el caso de $R$. longurio, las características de historia de vida le proveen de una mayor productividad biológica $y$, en consecuencia, pueden tener un papel importante en su resiliencia. La aplicación efectiva de las medidas de manejo, como la reciente aplicación de la veda (Diario Oficial de la Federación, México, 11 de junio de 2012) establecida en aguas mexicanas para proteger algunas especies de tiburón durante su época de reproducción, es necesaria. Además, son urgentes las investigaciones acerca de las tendencias de captura e índices de abundancia para determinar los niveles óptimos de extracción en la región.

\section{Agradecimientos}

Este estudio fue financiado por el Instituto Nacional de Pesca (INAPESCA) de México. El primer autor fue apoyado con una beca doctoral del Consejo Nacional de Ciencia y Tecnología (CONACYT, México). Agradecemos los valiosos comentarios de Elizabeth Brooks para mejorar el manuscrito.

Compagno L, Krupp F, Schneider W. 1995. Tiburones. In: Fischer W, Krupp F, Schneider W, Sommer C, Carpenter KE, Niem VH (eds.), Guía FAO para la Identificación de Especies para los Fines de la Pesca para el Pacífico Centro-Oriental. Vol. II, Parte 1. FAO, Rome, pp. 648-743.

[CONAPESCA-INP] Comisión Nacional de Acuacultura y PescaInstituto Nacional de Pesca. 2004. Plan de Acción Nacional para el Manejo y Conservación de Tiburones, Rayas y Especies Afines en México. CONAPESCA-INP, SAGARPA, México, $85 \mathrm{pp}$.

Corro-Espinosa D, Márquez-Farías JF, Muhlia-Melo A. 2011. Size at maturity of the Pacific sharpnose shark Rhizoprionodon longurio in the Gulf of California, Mexico. Cienc. Mar. 37: 201-214.

Cortés E, Brown CA, Beerkircher LR. 2007. Relative abundance of pelagic sharks in the western North Atlantic Ocean, including the Gulf of Mexico and Caribbean Sea. Gulf Caribb. Res. 19: $135-145$.

Cruz A, Soriano SR, Santana H, Ramírez CE, Valdez JJ. 2011. La pesquería de tiburones oceánicos-costeros en los litorales de Colima, Jalisco y Michoacán. Rev. Biol. Trop. 59: 655-667.

Doak DF, Bigger D, Harding EK, Marvier MA, O'Malley RE, Thomson D. 1998. The statistical inevitability of stabilitydiversity relationships in community ecology. Am. Nat. 151: 264-276. 
Dulvy NK, Sadovy Y, Reynolds JD. 2003. Extinction vulnerability in marine populations. Fish Fish. 4: 25-64.

Fowler SL, Cavanagh RD, Camhi M, Burgess GH, Cailliet GM, Fordham SV, Simpfendorfer CA, Musick JA. (comps. and eds.). 2005. Sharks, Rays and Chimaeras: The Status of the Chondrichthyan Fishes. Status Survey. IUCN/SSC Shark Specialist Group, IUCN, Gland, Switzerland, and Cambridge, UK, $461 \mathrm{pp}$.

Furlong-Estrada E, Barragán-Cuencas OV. 1997. Análisis biológico pesquero de tiburones de la familia Carcharhinidae (Elasmobranchii) capturados por la principal flota artesanal del sur de Nayarit México: Temporada 1995-1996. BSc thesis, Universidad de Guadalajara, México, 65 p.

Furlong-Estrada E, Tovar-Ávila J, Ríos-Jara E. 2014. Evaluación de riesgo ecológico de la pesca artesanal para los tiburones capturados en la entrada del golfo de California. Hidrobiológica 24: 83-97.

Gallegos-Camacho R. 2009. Determinación de la edad del tiburón martillo Sphyrna lewini en las costas de Nayarit, México. BSc thesis, Instituto Tecnológico del Mar de Bahía de Banderas, Nayarit, México, 82 p.

Gallegos-Camacho R, Tovar-Ávila J. 2011. Estimación de las longitudes total, furcal y patrón de juveniles de tiburón martillo, Sphyrna lewini (Carcharhiniformes: Sphyrnidae), a partir de las longitudes alternativa e interdorsal. Cienc. Pesq. 19: 39-43.

Hernández-Carvallo A. 1967. Observations on the hammerhead sharks (Sphyrna) in waters near Mazatlán, Sinaloa, Mexico. In: Gilbert PW, Mathewson RF, Rall DP (eds.), Sharks, Skates and Rays. John Hopkins University Press, Baltimore, MD, pp. 79-84.

Hoenig JM. 1983. Empirical use of longevity data to estimate mortality rates. Fish. Bull. 82: 898-903.

Hoyos-Padilla EM, Ceballos-Vázquez BP, Galván-Magaña F. 2012. Reproductive biology of the silky shark Carcharhinus falciformis (Chondrichthyes: Carcharhinidae) off the west coast of Baja California Sur, Mexico. Aqua Int. J. Ichthyol. 18: 15-24.

Joung SJ, Chen CT, Lee HH, Liu KM. 2008. Age, growth, and reproduction of silky sharks, Carcharhinus falciformis, in northeastern Taiwan waters. Fish. Res. 90: 78-85.

Madrid J, Sánchez P, Ruiz A. 1997. Diversity and abundance of a tropical fishery on the Pacific shelf of Michoacán, Mexico. Estuar. Coast. Shelf Sci. 45: 485-495.

Márquez-Farías JF, Castillo-Géniz L. 1998. Fishery biology and demography of the Atlantic sharpnose shark, Rhizoprionodon terraenovae, from the southern Gulf of Mexico. Fish. Res. 39: 183-198.

Márquez-Farías JF, Corro-Espinosa D, Castillo-Géniz L. 2005. Observations on the biology of the Pacific sharpnose shark (Rhizoprionodon longurio, Jordan and Gilbert 1882), captured in southern Sinaloa, Mexico. J. Northwest Atl. Fish. Sci. 35: 107-114.

McAllister MK, Peterman RM, Gillis DM. 1992. Statistical evaluation of a large scale fishing experiment designed to test for a genetic effect of size-selective fishing on British Columbia pink salmon (Oncorhynchus gorbuscha). Can. J. Fish. Aquat. Sci. 49: 1294-1304.

Moncayo-Estrada R, Castro-Aguirre JL, De La Cruz-Agüero J. 2006. Lista sistemática de la ictiofauna de bahía de Banderas, México. Rev. Mex. Biodivers. 77: 67-80.

Mondragón-Sánchez LF. 2015. Demografía del tiburón sedoso Carcharhinus falciformis en el Pacífico Central Mexicano. MSc thesis, Universidad Nacional Autónoma de México, 64 pp.

Myers RA, Worm B. 2005. Extinction, survival, or recovery of large predatory fishes. Phil. Trans. R. Soc. B 360: 13-20.

Pérez-Jiménez JC. 2001. Análisis de la pesquería artesanal de tiburones y rayas de Isla Isabel, Nayarit, México. MSc thesis,
Centro de Investigación Científica y de Educación Superior de Ensenada, México, $75 \mathrm{pp}$.

Pérez-Jiménez JC. 2014. Historical records reveal potential extirpation of four hammerhead sharks (Spyrna spp.) in Mexican Pacific waters. Rev. Fish Biol. Fish. 24: 671-683.

Pérez-Jiménez JC, Venegas-Herrera A. 1997. Análisis biológicopesquero de tiburones de las familias Sphyrnidae, Alopiidae y Lamnidae (Elasmobranchii) capturados por la principal flota artesanal del sur de Nayarit, México: Temporada 1995-1996. BSc thesis, Universidad de Guadalajara, México, 62 pp.

Pérez-Jiménez J, Sosa-Nishizaki O, Furlong-Estrada E, CorroEspinoza D, Venegas-Herrera A, Barragán-Cuencas OV. 2005. Artisanal shark fishery at "Tres Marías" islands and Isabel Island in the central Mexican Pacific. J. Northwest Atl. Fish. Sci. 35: 333-343.

Ramírez-Santiago C, Hernández-Díaz RM, Figueroa-Núñez ML, Preciado-Gil D, Soriano-Velásquez SR, Acal-Sánchez D, Vázquez-Gómez N. 2006. Estimación de una medida alterna de tiburones en troncho desembarcados por la flota artesanal de bahía de Banderas, Nayarit, y Puerto Madero, Chiapas. Memorias del Segundo Simposio Nacional de Tiburones y Rayas, Universidad Nacional Autónoma de México, Mexico City, August 2006.

Sánchez de Ita JA, Quiñónez-Velázquez C, Galván-Magaña F, Bocanegra-Castillo N, Félix-Uraga R. 2010. Age and growth of the silky shark, Carcharhinus falciformis, in the northwest of Mexico. J. Appl. Ichthyol. 27: 20-24.

Santana-Hernández H, Flores-Valdez J. 2013. Pelágicos mayores obtenidos por la flota palangrera de mediana altura del puerto de Manzanillo, Colima. Instituto Nacional de Pesca, México, $63 \mathrm{pp}$.

Saucedo-Barrón CJ. 1982. El tiburón: Contribución al estudio de la pesquería en la zona sur de Sinaloa, México. Ciencias del Mar, Universidad Autónoma de Sinaloa. Epoca 1, 1: 14-29.

[SAGARPA] Secretaría de Agricultura, Ganadería, Desarrollo Rural, Pesca y Alimentación. 2012. Anuario Estadístico de Acuacultura y Pesca 2011, México, 308 pp.

[SEMARNAP] Secretaría del Medio Ambiente, Recursos Naturales y Pesca. 1998. Anuario Estadístico de Pesca 1997, México, $241 \mathrm{pp}$.

[SEMARNAP] Secretaría del Medio Ambiente, Recursos Naturales y Pesca. 2004. Anuario Estadístico de Pesca 2002, México, $266 \mathrm{p}$.

[SEPESCA] Secretaría de Pesca. 1988. Anuario Estadístico de Pesca 1987, México, 352 pp.

Shepherd TD, Myers RA. 2005. Direct and indirect fishery effects on small coastal elasmobranchs in the northern Gulf of Mexico. Ecol. Lett. 8: 1095-1104.

Simpfendorfer CA. 1999. Demographic analysis of the dusky shark fishery in southwestern Australia. In: Musick JA (ed.), Life in the Slow Lane: Ecology and Conservation of Long Lived Marine Animals. American Fisheries Society Symposium 23, Bethesda, MD, pp. 149-160.

Simpfendorfer CA. 2005. Demographic models: Life tables, matrix model and rebound potential. In: Musick JA, Bonfil R (eds.), Management Techniques for Elasmobranch Fisheries. FAO Fish. Tech. Pap. 474: 143-153.

Smith SE, Au DW, Show C. 1998. Intrinsic rebound potentials of 26 species of Pacific sharks. Mar. Freshwat. Res. 48: 663-678.

Smith WD, Márquez-Farias JF, Pérez-Jiménez JC. 2009. Rhizoprionodon longurio. In: IUCN 2012. IUCN Red List of Threatened Species. Version 2012.1. Available at: www.iucnredlist.org. Downloaded on 26 September 2012. 
Soriano-Velásquez SR, Ramírez-Santiago CE, Vázquez-Gómez N, Ulloa-Ramírez PA, Hernández-Díaz RM, Solis-Gil C, FigueroaNúñez ML, Rodríguez-Hernández DM, Preciado-Gil D. 2005. Diagnóstico de la pesquería artesanal de tiburones en la Cruz de Huanacaxtle, bahía de Banderas, Nayarit, México. Informe de Investigación, Instituto Nacional de la Pesca, México, 44 pp.

Soriano-Velásquez SR, Acal-Sánchez DE, Castillo-Géniz JL, Vázquez-Gómez N, Ramírez-Santiago CE. 2006. Tiburones del Golfo de Tehuantepec. In: Arreguín-Sánchez F, BeléndezMoreno LF, Méndez Gómez-Humarán I, Solana-Sansores R, Rangel-Dávalos C (eds.), Sustentabilidad y Pesca Responsable en México. Instituto Nacional de la Pesca, SAGARPA, México, pp. 323-360.

Stevens JD, Bonfil R, Dulvy NK Walker PA. 2000. The effects of fishing on sharks, rays, and chimaeras (chondrichthyans), and the implications for marine ecosystems. ICES J. Mar. Sci. 57: 476-494.

Torres-Herrera MR, Tovar-Ávila J. 2014. Variación temporal de la captura de tiburón en las islas y costa central de Nayarit, México, con base en los registros oficiales de desembarque. Hidrobiológica 24: 99-107.
Torres-Huerta AM, Villavicencio-Garayzar C, Corro-Espinoza D. 2008. Biología reproductiva de la cornuda común Sphyrna lewini (Griffith y Smith) (Sphyrnidae) en el golfo de California. Hidrobiológica 18: 227-238.

Tovar-Ávila J, Day RW, Walker TI. 2010. Using rapid assessment and demographic methods to evaluate the effects of fishing on Hetreodontus portusjacksoni off far-eastern Victoria, Australia. J. of Fish Biol. 77 (7): 1568-1578.

Tovar-Ávila J, Zarate-Becerra ME, Patiño-Valencia JL, Green-Ruíz Y, Toledo-Díaz Rubín P, De la Cruz-González FJ, TorresHerrera MR, Espinosa Partida B, Ulloa-Ramírez PA, FurlongEstrada E, Mondragón Sánchez LF, Preciado-Robles Gil D, Hernández-Corona JL, Braccini M. 2011. Análisis integral de la pesquería de tiburón en Nayarit. Informe de Investigación. INAPESCA, México. 86 pp.

Walker TI. 1998. Can shark resources be harvested sustainably? A question revisited with a review of shark fisheries. Mar. Freshwat. Res. 49: 553-572.

Wholfarth GW. 1986. Decline in natural fisheries: A genetic analysis and suggestion for recovery. Can. J. Fish. Aquat. Sci. 43: 1298-1306.

Received July 2014, accepted February 2015. 